\title{
Integrated Weed Management in Maize (Zea mays L.) for Sustainable Productivity and Profitability of Maize-Wheat Cropping System in Southern Rajasthan
}

\author{
Hargilas
}

Agricultural Research Station (MPUAT), Borwat farm, Banswara, Rajasthan (327 001), India

\section{Article History}

Manuscript No. AR1607

Received in $31^{\text {st }}$ May, 2016

Received in revised form $6^{\text {th }}$ June, 2016

Accepted in final form $7^{\text {th }}$ June, 2016

\section{Correspondence to}

*E-mail: hargilasm73@gmail.com

\section{Keywords}

Maize, weed, cover crop, yield, B:C ratio

\begin{abstract}
A field experiment was conducted during two consecutive years of 2010-2011 and 2011-2012 to identify the most effective integrated weed management (IWM) practice for enhancing the production and productivity of maize-wheat cropping system. The treatments included pre-emergence herbicides, PE (Atrazine, metribuzin and oxyfluorfen) with and without hoeing, post-emergence herbicides, PoE $(2,4-\mathrm{D})$, and smother crop (two rows of cowpea) simultaneously raised and mulched at 25 days after sowing (DAS) with weedy and weed-free check. The study found that the maximum maize grain yield of $5837 \mathrm{~kg} \mathrm{ha}^{-1}$ occurred in the weed-free plot which was at par with the yield obtained from the maize+cowpea (raised as smothering crop and mulched at 25 DAS). Three treatments demonstrated increased grain yield of maize 73.04, 77.12 and 76.65\% under mean of PE, PE+PoE and PE+one hoeing over weedy check, respectively. Furthermore, the treatments provided not only effective smothering-effects on weeds, but also significantly higher-yields in the succeeding wheat crop (5684 $\left.\mathrm{kg} \mathrm{ha}^{-1}\right)$ under maize-wheat rotation. The highest benefit to cost (B: C) ratio was 2.69 with system productivity $11919 \mathrm{~kg} \mathrm{ha}^{-1}$ when weed control in maize was achieved by smothering and mulching effects of cowpea. The results indicated that inclusion of cowpea as smother crop in between maize rows and it mulched at 25 days after sowing (DAS) offers a promising, cost-effective and efficient system for weed management in maize and is also provided an eco-friendly approach against herbicides application for sustaining the maize-wheat cropping system.
\end{abstract}

\section{Introduction}

After rice, maize and wheat are the major cereal's crops contributing to food security and farm income in India. Major area of maize is cultivated during kharif season in which weed's infestation is one of the most important yield-limiting factors because maize is planted in wide spaced rows with heavy nutrients. However, the most critical period for crop-weed competition is first six weeks after planting of crop, because initial slow growth in wider spacing of maize, coupled with congenial weather conditions allow luxuriant weed growth which might be reduced yield by $28-100 \%$ (Dass et al., 2012; Pandey et al., 1999). The critical period of crop-weed competition in maize during the rainy season was reported from 15-45days after sowing (Kumar et al., 2015). Weeds are not only competing with crop for water, nutrient, light and space but also provide harbor for insect-pests. During the critical period, the practice of repeated hands weeding and mechanical operations are still widely adopted but these are more expensive and several times operations are not possible timely due to incessant rains. Therefore, the use of PE and POE herbicides with some amount of mechanical operation would necessary to keep the crop safe during initial crop growth stage. Herbicide like atrazine, pendimethalin, metribuzin, fluchlorin alone or in combination applied as pre-planting and pre-emergence and 2,4-D applied as post-emergence stage were widely evaluated but no single combination was found uniform effective.

Presently, atrazine is widely used as pre-emergence herbicide in maize but do not provides effective control of many weeds like Cyperus rodundus and Echinochloa cruss-gallis (Kandasamy and Chandrasekher, 1998) and also do not controlled for longer period results poor weed control efficiency. Whereas, the use of atrazine herbicide as pre-emergence spray followed by two weeding with one hoeing operation is common practice for weed management in kharif maize in southern Rajasthan but mechanical weeding is partially ineffective because weeds also grow in intra rows space and manual weeding is also impossible in incessant rains. Some information about cover 
crops is used instead of chemical herbicides. This type of information could be very useful in economizing the use of cover crop in preceding crop and reducing hazard effect of chemical in succeeding crop. Similarly, the impact of cowpea intercropped with maize on succeeding wheat was also positive (Singh et al., 2015). Therefore, the present investigation was under taken to find out effective practices to manage all kind of weed flora in maize and their effects on succeeding wheat crop grown under sequential cropping.

\section{Materials and Methods}

A field experiment was conducted in two consecutive years from 2010-11 to 2011-12 in maize-wheat crop rotation on the fixed site at Agricultural Research Station (MPUAT), Banswara. It is geographically situated at $23^{\circ} 33^{\prime} \mathrm{N}$ latitude, $74^{\circ} 27^{\prime} \mathrm{E}$ longitude, and altitude of $220 \mathrm{~m}$ amsl. It is covered under humid southern plain agro-climatic zone of Rajasthan, which falls under sub-humid climate with dry, hot summer and mild winters. The mean maximum temperature was for the month of June which range from $40-45^{\circ} \mathrm{C}$. The average annual rainfall is about $862 \mathrm{~mm}$ of which more than $80 \%$ is generally received during the monsoon season (June-October). The soil of experimental field was clay loam in texture, slightly alkaline in reaction with low in organic carbon $(0.41 \%)$, low in available nitrogen $\left(218 \mathrm{~kg} \mathrm{ha}^{-1}\right)$, medium in available phosphorus $(22.6 \mathrm{~kg}$ $\left.\mathrm{ha}^{-1}\right)$ and high available potassium $\left(378 \mathrm{~kg} \mathrm{ha}^{-1}\right)$. A combination of ten treatments comprising application of atrazine @ $1.0 \mathrm{~kg}$ a.i. ha ${ }^{-1}$ as pre-emergence (PE) $\left(\mathrm{T}_{1}\right)$, metribuzine @ $0.25 \mathrm{~kg}$ a.i. ha ${ }^{-1} \mathrm{PE}\left(\mathrm{T}_{2}\right)$, oxyfluorfen @ $0.15 \mathrm{~kg} \mathrm{ha}^{-1} \mathrm{PE}\left(\mathrm{T}_{3}\right)$, atrazine (a) $0.5 \mathrm{~kg}$ a.i. ha ${ }^{-1} \mathrm{PE}$ followed by (fb) 2,4DEE @ $0.4 \mathrm{~kg}$ a.i. ha $^{-1}$ as post-emergence (PoE) at $25 \mathrm{DAS}\left(\mathrm{T}_{4}\right)$, Maize + cowpea (2 rows) raised as smother crop fb mulched with one hoeing at 25DAS $\left(\mathrm{T}_{5}\right)$, Atrazine @ 1.0 a.i. ha ${ }^{-1} \mathrm{PE}+1$ hand hoeing 25 DAS ( $\left.\mathrm{T}_{6}\right)$, Metribuzin @ $0.25 \mathrm{~kg}$ a.i. ha ${ }^{-1} \mathrm{PE}+1$ hand hoeing at 25 DAS $\left(\mathrm{T}_{7}\right)$, oxyfluorfen @ $0.1 \mathrm{~kg}$ a.i. ha ${ }^{-1} \mathrm{PE}+1$ hand hoeing $\left(\mathrm{T}_{8}\right)$, Weedy check $\left(\mathrm{T}_{9}\right)$, and weed free $\left(\mathrm{T}_{10}\right)$ were laid out in randomized block design with three replications. The seed of maize single cross hybrid HQPM 1 was dibbled manually at spacing of $60 \times 25 \mathrm{~cm}^{2}$ using $20 \mathrm{~kg}$ seed ha- in first week of July during both the years of 2010 and 2011, respectively and fertilized with $120+60+40 \mathrm{~kg} \mathrm{~N}+\mathrm{P}_{2} \mathrm{O}_{5}+\mathrm{K}_{2} \mathrm{O} \mathrm{ha}^{-1}$. The full dose of $\mathrm{P}$ and $\mathrm{K}$ and $1 / 3$ dose of nitrogen were applied at the time of sowing as basal application, whereas the remaining dose of nitrogen was applied in two equal splits at knee high and tasseling stages. All herbicides were applied using water @ $5001 \mathrm{ha}^{-1}$ with the help of knapsack sprayer fitted with flat fan nozzle. The succeeding wheat crop cv Raj 3077 was sown on last week of November and harvested on first week of April during both the years of 2010-11 and 2011-12, respectively. The wheat crop was fertilized with $40+60+40 \mathrm{~kg} \mathrm{~N}+\mathrm{P}_{2} \mathrm{O}_{5}+\mathrm{K}_{2} \mathrm{O}$ $\mathrm{ha}^{-1}$ at sowing as basal and $80 \mathrm{~kg} \mathrm{~N}$ was applied as top dressed in two equal split with first irrigation at 21 DAS and second irrigation at 45 DAS. All other practices were fallowed as per recommendation of both crops. The weedy check (control) was kept undisturbed for the entire cropping period of the kharif maize crop. To see the residual effects of the treatment applied in maize, the wheat crop was raised with recommended weed management practices.

Data pertaining to weed population and dry weight were recorded at harvest in maize crop from two places in each plot using $100 \times 100 \mathrm{~cm}^{2}$ quadrate and counted species-wise. The efficiency of weed management treatment was assessed by weed control efficiency (WCE) and weed index (WI) that were calculated as

$$
\operatorname{WCE}(\%)=\frac{\mathrm{WD}_{\mathrm{c}}-\mathrm{WD}_{\mathrm{t}}}{\mathrm{WD}_{\mathrm{c}}} \times 100
$$

Where WDc is weeds dry weight $\left(\mathrm{g} \mathrm{m}^{-2}\right)$ in control plot and WDt is weed dry weight $\left(\mathrm{g} \mathrm{m}^{-2}\right)$ in the respective treatment

$$
\text { Weed index }=\frac{x-y}{x} \times 100
$$

Where $x$ is grain yield of maize in weed free plots and $y$ is the grain yield of maize in the respective treatment.

System productivity in terms of maize equivalent yield was calculated by adding the grain yield of maize with maize equivalent yield of wheat calculated using market price for both crops in respective years. The cost of cultivation under various treatments was estimated based on prevailing rates of inputs at Banswara. The input cost included in cost of seed, herbicide treatment application, chemical fertilizers and the hoeing charges of human labour and machines for land preparation, irrigation, fertilization, harvesting and threshing. Gross returns were calculated by multiplying maize equivalent yield of the system with market price of maize in both the years. The net returns were calculated with respect to each treatment by subtracting the total cost of cultivation from gross returns. The benefit: cost ratio were calculated for each treatment applied in the system as the ratios of net returns to cost of cultivation. Analysis of variance (ANOVA) was done to determine treatment effects by using statistically analyzed procedure given by Gomez and Gomez (2010).

\section{Results and Discussion}

\subsection{Effect of different weed control treatment of weed flora}

The weed flora of the experimental field indicated the presence of $60 \%$ grassy weeds and $40 \%$ broad-leaved weeds. Echinochloa crusgalli, Dactyloctenium agypticum Eleusine indica, Panicum repense, Eragrostis sp. Digitaria ramose, Dinebra retroxa, Cynodon datylon, Cyperus rotundus, Sorghum helepense were dominat grassy species while Trianthema portulacastrum, Commelina benghalensis, 
Amaranthus viridis, Cleome viscosa, Alternenthera echinata, Euphorbia genicullata, Euphorbia hirta, Phylanthus niruri, Digera arvensis, Abutilon indicum, Eclipta alba, Achalypha indica, Parthenium hysterophorus, Xanthium strumarium, Tribulus terrestris, Acaranthus aspera were dominated broad leaved weeds.

Pooled data of kharif season of two consecutive years presented in Table 1 showed that the maximum weed density $\left(324.9 \mathrm{~m}^{-2}\right)$ and weed dry weight $\left(188.10 \mathrm{~g} \mathrm{~m}^{-2}\right)$ at 30 DAS and weed dry weight $\left(238 \mathrm{~g} \mathrm{~m}^{-2}\right)$ at 60 DAS were recorded in the weedy check treatment. All treatments recorded significant reduced in density and dry weight of weeds compared to weedy check at respective stages. Nadiger et al. (2013) reported that the density and dry weight of weeds were significantly reduced with application of herbicides compared to weedy check. The weed flora was difficult to control by pre-emergence herbicides application of either atrazine, or metribuzine or oxyfluorfen alone. Board leaf weeds were significantly controlled by sequencing application of atrazine @ $1.0 \mathrm{~kg}$ a.i. ha-1 PE fallowed by 2,4DEE@0.4 kg a.i. ha-1 POE at 25
DAS. However, the total weed flora was significantly reduced with the application of pre-emergence herbicides fallowed by one hand weeding at 25 DAS. The new herbicides namely metribuzine and oxyfluorfen were found more effective than atrazine. Sharma and Thakur (1998) reported the poor efficiency of atrazine against many weeds in maize. Singh et al. (2015) reported that weeds were effectively controlled by metribuzine@0.25 kg a.i. ha ${ }^{-1}$ follewd by one hand weeding at 21 DAS. However, Nadiger et al. (2013) also reported that oxyfluorfen@0.15 kg ha ${ }^{-1}$ was more effective than other herbicides. The better results of these herbicides might be due to longer persistence effect. While under hand weeding, it could be attributed to reduced crop weed competition in the initial stage and removal of the late germinated weeds by hand weeding at 25 DAS. The encouraging results for smothering effect of maize+cowpea were recorded on growth and density of weeds as most of these weeds were suppressed by live mulching of cowpea. Cowpea had such a large effect on weed suppression due to its ability to develop over-ground runners, which occupied the inter-row spacing and restricted

Table 1: Effect of weed management practices on weed flora, weed control efficiency and weed index in maize (pooled data of two years)

\begin{tabular}{|c|c|c|c|c|c|c|c|c|c|}
\hline Treatment & $\begin{array}{l}\text { No. of } \\
\text { Broad } \\
\text { leaf } \\
\text { (weeds } \\
\mathrm{m}^{-2} \text { ) }\end{array}$ & $\begin{array}{c}\text { Grassy } \\
\text { intensity } \\
\left(\text { weeds } \mathrm{m}^{-2} \text { ) }\right.\end{array}$ & $\begin{array}{l}\text { Sedge } \\
\text { intensity } \\
\text { (weeds } \\
\mathrm{m}^{-2} \text { ) }\end{array}$ & $\begin{array}{c}\text { Weed } \\
\text { intensity } \\
\text { (weeds } \mathrm{m}^{-2} \text { ) }\end{array}$ & $\begin{array}{c}\text { Weed } \\
\text { dry mat- } \\
\text { ter at } 30 \\
\text { DAS } \\
\left(\mathrm{g} \mathrm{m}^{-2}\right)\end{array}$ & $\begin{array}{c}\text { Weed } \\
\text { control } \\
\text { efficiency } \\
\text { at } 30 \\
\text { DAS } \\
(\%)\end{array}$ & $\begin{array}{l}\text { Weed } \\
\text { dry mat- } \\
\text { ter at } 60 \\
\text { DAS } \\
\left(\mathrm{g} \mathrm{m}^{-2}\right)\end{array}$ & $\begin{array}{l}\text { Weed } \\
\text { control ef- } \\
\text { ficiency at } \\
60 \text { DAS } \\
(\%)\end{array}$ & $\begin{array}{c}\text { Weed } \\
\text { index } \\
(\%)\end{array}$ \\
\hline $\begin{array}{l}\mathrm{T}_{1}: \text { Atrazine @ } 1.0 \mathrm{~kg} \\
\text { a.i. ha }{ }^{-1} \mathrm{PE}\end{array}$ & 18.6 & 59.0 & 3.8 & 81.4 & 47.13 & 74.95 & 122.54 & 48.51 & 50.47 \\
\hline $\begin{array}{l}\mathrm{T}_{2}: \text { Metribuzin @0.25 } \\
\mathrm{kg} \text { a.i. ha }{ }^{-1} \mathrm{PE}\end{array}$ & 12.8 & 52.7 & 2.1 & 67.6 & 39.14 & 79.14 & 102.55 & 56.91 & 41.38 \\
\hline $\begin{array}{l}\mathrm{T}_{3}: \text { Oxyfluorfen@ } \\
0.15 \mathrm{~kg} \mathrm{ha}^{-1} \mathrm{PE}\end{array}$ & 12.4 & 48.6 & 4.8 & 65.8 & 38.09 & 79.75 & 96.75 & 59.35 & 41.95 \\
\hline $\begin{array}{l}\mathrm{T}_{4} \text { : Atrazine @ } 0.5 \mathrm{~kg} \\
\text { a.i. ha-1 } \mathrm{PE} \mathrm{fb} 2,4 \mathrm{DEE} \\
\text { @ } 0.4 \mathrm{~kg} \text { a.i. ha }{ }^{-1} \mathrm{POE} \\
\text { at } 25 \mathrm{DAS}\end{array}$ & 8.6 & 39.8 & 3.3 & 51.7 & 29.93 & 84.09 & 68.84 & 71.08 & 35.00 \\
\hline $\mathrm{T}_{5}:$ Maize+cowpea* & 8.30 & 20.0 & 1.4 & 29.7 & 17.19 & 90.86 & 22.35 & 90.61 & 8.77 \\
\hline $\begin{array}{l}\mathrm{T}_{6}: \text { Atrazine@1.0 a.i. } \\
\mathrm{ha}^{-1} \mathrm{PE}+1 \mathrm{H}\end{array}$ & 10.8 & 20.8 & 13.4 & 45.0 & 26.05 & 86.15 & 62.52 & 73.73 & 36.90 \\
\hline $\begin{array}{l}\mathrm{T}_{7}: \text { Metribuzin@ } 0.25 \\
\mathrm{~kg} \text { a.i. ha } \mathrm{ha}^{-1}+1 \mathrm{H}\end{array}$ & 8.8 & 18 & 3.2 & 30.0 & 17.37 & 90.77 & 55.58 & 76.65 & 31.81 \\
\hline $\begin{array}{l}\mathrm{T}_{8}: \text { Oxyfluorfen } @ \\
0.15 \mathrm{~kg} \mathrm{ha}^{-1}+1 \mathrm{H}\end{array}$ & 10.3 & 12.7 & 2.6 & 25.6 & 14.82 & 92.72 & 50.39 & 78.83 & 38.96 \\
\hline $\mathrm{T}_{9}:$ Weedy check & 60.8 & 245.6 & 18.5 & 324.9 & 188.10 & 00 & 238.00 & 0.00 & 85.06 \\
\hline $\mathrm{T}_{10}:$ Weed free & 5.3 & 6.0 & 4.0 & 15.3 & 8.86 & 95.29 & 11.52 & 95.16 & 0.00 \\
\hline $\mathrm{CD}(p=0.05)$ & 3.20 & 12.80 & 556 & 1.12 & 9.12 & & 11.12 & & 9.17 \\
\hline
\end{tabular}

*Two rows of cowpea raised in maize as smother crop followed by mulched at 25 DAS; H: Hand hoeing at 25 DAS 
the germination and growth of weeds. Many previous studies have also conformed reduction of density and dry matter of weeds in system that use cover crops by covering the inter-row spaces, which ultimately suppresses weed emergence (Dubey, 2008; Singh et al., 2015).

\subsection{Weed control efficiency and weed index}

Pooled data on weed control efficiency and weed index presented in Table 1 revealed that the maximum weed control efficiency of different weed control measures ranged from $74.95-95.29 \%$ at 30 DAS and $48.51-95.16 \%$ at 60 DAS. Highest weed control efficiency (95.26\%) was achieved with weed free treatment which closely followed by oxyfluorfen (a) $0.15 \mathrm{~kg} \mathrm{ha}^{-1} \mathrm{PE}+1$ hoeing at $25 \mathrm{DAS}$ and maize+cowpea ( 2 rows) raised as smother crop fb mulched with 1 hoeing at 25DAS (90.86\%). However, weed control efficiency of maize + cowpea was recorded $14.19,7.45$ and $5.18 \%$ superior over mean of pre emegence herbicides, atrazine @ $0.5 \mathrm{~kg}$ ha $^{-1}$ PE fallowed by 2,4-DEE @ $0.4 \mathrm{~kg}$ a.i. ha ${ }^{-1}$ POE at 25 DAS and atrazine +1 hand hoeing at 25 DAS, respectively. Whereas, weed control efficiency of maize + cowpea treatment at 60 DAS was recorded 39.83,21.56 and $15.68 \%$ superior over mean of PE, PE+PoE and PE followed by one hoeing at $25 \mathrm{DAS}$, respectively. Whenever, weed index of different treatments ranged from $8.77-85.06 \%$. The maize+cowpea as smother crop mulched with one hoeing at 25 DAS recorded lowest weed index, which was at par with weed free treatment and significantly superior over rest treatments. It clearly shows that maize+cowpea treatment resulted higher weed control efficiency and lower weed index due to smothering effect of cowpea on weed growth. Therefore, it is advisable that maize can be intercropped with short duration legume such as cowpea as living mulches, which reduces weed density with effect on maize yield. Living mulches suppress weeds by competing for the use of growth resources and changing environmental factors that affect weed germination and establishment and can ultimately result in reduced herbicide application (Liebman and Davis, 2000). Cowpea had significant effect on weed suppression due to its ability to develop over-ground foliage, which occupied the inter-row spaces of intercropping treatment and restricted the germination of weed seeds and growth of weeds. Many workers reported lower weeds and their dry weights in various cropping systems by using cover crops because it covers the inter-row spaces and suppresses weed emergence (Teasdale and Mohler, 1993).

\subsection{Yield attributed and grain yield}

\subsubsection{Maize}

Grains yield during both the years of experiment (Table 2) was found differed significantly due to weed management treatments. The highest grain yield $\left(5837 \mathrm{~kg} \mathrm{ha}^{-1}\right)$ was obtained in weed free plot $\left(\mathrm{T}_{10}\right)$ which was statistically at par with the treatment of maize+cowpea $\left(5287 \mathrm{~kg} \mathrm{ha}^{-1}\right)$. The grain yield obtained under this treatment $\left(\mathrm{T}_{5}\right)$ however, was significantly superior over rest of weed management treatments including weedy check, having the grain yield of $864 \mathrm{~kg} \mathrm{ha}^{-1}$ with yield reduction of 85 and $83 \%$ over $\mathrm{T}_{10}$ and $\mathrm{T}_{5}$, respectively. The increased grain yield in maize+cowpea can be attributed to significant production of cob's yield $\left(7402 \mathrm{~kg} \mathrm{ha}^{-1}\right)$ and reduced number of weeds during initial stage under suppressed the weed to smother effect of cowpea while subsequent weed flushes were control by mulching of cowpea in between rows

Table 2: Effect of IWM in maize on yield attributes, yield and system productivity of maize-wheat rotation (pooled data of two years)

\begin{tabular}{|c|c|c|c|c|c|c|}
\hline Treatment & $\begin{array}{c}\text { Cob yield } \\
\text { of maize } \\
\left(\mathrm{kg} \mathrm{ha}^{-1}\right)\end{array}$ & $\begin{array}{c}\text { Grain yield } \\
\text { of maize } \\
\left(\mathrm{kg} \mathrm{ha}^{-1}\right)\end{array}$ & $\begin{array}{l}\text { No of } \\
\text { tillers } \\
\text { plant }^{-1}\end{array}$ & $\begin{array}{l}\text { Grain yield } \\
\text { of wheat } \\
\left(\mathrm{kg} \mathrm{ha}^{-1}\right)\end{array}$ & $\begin{array}{c}\mathrm{MEY} \\
\left(\mathrm{kg} \mathrm{ha}^{-1}\right)\end{array}$ & $\begin{array}{c}\text { System } \\
\text { productivity } \\
\left(\mathrm{kg} \mathrm{ha}^{-1}\right)\end{array}$ \\
\hline $\mathrm{T}_{1}$ : Atrazine @1.0 kg a.i. ha ${ }^{-1} \mathrm{PE}$ & 3819 & 2850 & 4.01 & 4222 & 4926 & 7776 \\
\hline $\mathrm{T}_{2}:$ Metribuzin@0.25 kg a.i. ha ${ }^{-1} \mathrm{PE}$ & 4300 & 3386 & 4.05 & 4272 & 4984 & 8370 \\
\hline $\mathrm{T}_{3}$ : Oxyfluorfen@0.15 kg ha ${ }^{-1} \mathrm{PE}$ & 4391 & 3378 & 4.12 & 4315 & 5034 & 8412 \\
\hline $\begin{array}{l}\mathrm{T}_{4}: \text { Atrazine } 0.5 \mathrm{~kg} \text { a.i. ha }{ }^{-1} \mathrm{PE} \text { fb } 2,4 \mathrm{DEE} \\
\text { @ } 0.4 \mathrm{~kg} \text { a.i. ha } \mathrm{ha}^{-1} \mathrm{POE} \text { at } 25 \mathrm{DAS}\end{array}$ & 4984 & 3776 & 4.14 & 4434 & 5173 & 8949 \\
\hline $\mathrm{T}_{5}:$ Maize+cowpea* & 7402 & 5287 & 5.30 & 5684 & 6631 & 11919 \\
\hline $\mathrm{T}_{6}:$ Atrazine @1.0 a.i. ha ${ }^{-1} \mathrm{PE}+1 \mathrm{H}$ & 4972 & 3656 & 4.34 & 4650 & 5425 & 9081 \\
\hline $\mathrm{T}_{7}$ : Metribuzin@0.25 kg a.i. ha ${ }^{-1}+1 \mathrm{H}$ & 5127 & 3884 & 4.27 & 4580 & 5343 & 9290 \\
\hline $\mathrm{T}_{8}$ : Oxyfluorfen@0.15 kg ha ${ }^{-1}+1 \mathrm{H}$ & 4842 & 3560 & 4.27 & 4460 & 5203 & 8763 \\
\hline $\mathrm{T}_{9}:$ Weedy check & 1063 & 864 & 3.38 & 3640 & 4247 & 5110 \\
\hline $\mathrm{T}_{10}$ : weed free & 8289 & 5837 & 4.84 & 5178 & 6041 & 11878 \\
\hline $\mathrm{CD}(p=0.05)$ & 970 & 566 & 0.54 & 598 & 697 & 1035 \\
\hline
\end{tabular}

${ }^{*}$ Two rows of cowpea raised in maize as smother crop followed by mulched at 25 DAS; H: Hand hoeing at 25 DAS 
of maize with one hand hoeing at 25 DAS. similar findings also reported that growth suppression periods of cowpea living mulch decreased weed growth due to either changes in soil temperature, release of allopathic chemicals, or physical impediments to weed seedlings (Teasdale, 1996) and retain cowpea living mulch could be increased grain yield due to better weed control, increased moisture availability, reduced resources competitions (Talebbeigi and Ghadiri, 2012). Maize is characterized an a nitrophilic crop and therefore, the potential biological nitrogen fixing abilities of legume crops such as cowpea would bring further benefits by reducing the amount of $\mathrm{N}$ fertilization needed for maize crop. Inclusion of cover crops in to weed management strategy for either individual crop or in cropping sequence will be a cost-effective and environment, improve soil fertility and ultimately enhanced the crop yield.

\subsubsection{Wheat}

The pooled yield of wheat of both the years (2010-11 and 2011-12) varied from $3640-5684 \mathrm{~kg} \mathrm{ha}^{-1}$ with residual effects of proceeding crop (Table 3). The lowest grain yield (3640 $\mathrm{kg} \mathrm{ha}^{-1}$ ) was obtained in the weedy check and highest grain yield $\left(5684 \mathrm{~kg} \mathrm{ha}^{-1}\right)$ obtained in maize+cowpea might be due to lowest number of tillers plant ${ }^{-1}$ (3.38) in weedy check and highest number of tillers plant ${ }^{-1}(5.12)$ in maize+cowpea. It shows that ability of soil to supply nutrient is limited and the nutrient applied to kharif maize have significant residual effect may be either positive or negative on succeeding wheat crop. Therefore, the carrying capacity of soil in both the cases reflected as system productivity was more than $11 \mathrm{t} \mathrm{ha}^{-1}$ in maize + cowpea cover crop. The treatment of maize + cowpea in preceeding crop was significantly increased pooled grain yield of wheat by $24.88,21.99,19.72$ and $35.96 \%$ over mean yield of PE $\left(\mathrm{T}_{1}-\mathrm{T}_{3}\right), \mathrm{PE}+\mathrm{PoE}\left(\mathrm{T}_{4}\right), \mathrm{PE}+1$ hoeing $\left(\mathrm{T}_{6}-\mathrm{T}_{8}\right)$ and weedy check, respectively. It presented that the residual effect of cowpea intercrop with maize resulted in potential biological nitrogen fixing abilities of cowpea that brought beneficial effect on realization of wheat yield. Dubey (2008) also reported beneficial residual effect of cowpea on succeeding wheat crop to increase of $14-18 \%$ in grain yield of wheat due to preceding treatment combination of cowpea in maize.

\subsection{System productivity}

The pooled of system productivity of both the years was calculated maximum (11919 kg ha $\left.{ }^{-1}\right)$ with weed control in maize by smothering effects of growing cowpea and it's mulched at 25 DAS in maize+cowpea treatment that was found significantly $31.32,24.92,24.11$ and $57.12 \%$ superior over mean of PE, PE $+\mathrm{PoE}, \mathrm{PE}+1$ hoeing and weedy check treatments, respectively. The results indicated that inclusion of cowpea in maize not only control weed in maize but it also increased succeeding wheat crop yield and ultimately resulting in significantly higher system productivity. Adigbo et al. (2013) also reported that alternate row additive and alternate stand spatial arrangements have the potential to enhance the productivity of two cowpea varieties without reducing maize yield in derived savannah of Nigeria. Nitrogen fixation from legume makes "free" $\mathrm{N}$ for use by the host plant or by associated or subsequent crops as legume effect. Replacing it with fertilizer $\mathrm{N}$ would cost $\$ 7$ to 10 billion annually, whereas even modest use of alfalfa in rotation with corn could save farmers \$200 to 300 million (Peterson and Russelle, 1991). The most common goal of intercropping is to produce a higher yield on a given piece of land by making use of resources that would otherwise not be utilized by a single crop.

Table 3: Economics of maize-wheat system under various weed management practices applied in maize (pooled data of two years)

\begin{tabular}{|c|c|c|c|c|}
\hline Treatment & $\begin{array}{l}\text { Gross returns } \\
\left(₹ \mathrm{ha}^{-1}\right)\end{array}$ & $\begin{array}{c}\text { Cost of } \\
\text { cultivation }\left(₹ \mathrm{ha}^{-1}\right)\end{array}$ & $\begin{array}{l}\text { Net returns } \\
\left(₹ \text { ha }^{-1}\right)\end{array}$ & $\mathrm{B}: \mathrm{C}$ ratio \\
\hline $\mathrm{T}_{1}$ : Atrazine $@ 1.0 \mathrm{~kg}$ a.i. ha ${ }^{-1} \mathrm{PE}$ & 93309 & 36590 & 56719 & 1.55 \\
\hline $\mathrm{T}_{2}:$ Metribuzin @0.25 kg a.i. ha-1 $\mathrm{PE}$ & 100435 & 37150 & 63285 & 1.70 \\
\hline $\mathrm{T}_{3}$ : Oxyfluorfen @0.15 kg ha-1 PE & 100941 & 37475 & 63466 & 1.69 \\
\hline $\begin{array}{l}\mathrm{T}_{4} \text { : Atrazine @ } 0.5 \mathrm{~kg} \text { a.i. ha-1 PE fb 2,4DEE @ } 0.4 \mathrm{~kg} \text { a.i. } \\
\text { ha }^{-1} \text { POE at } 25 \mathrm{DAS}\end{array}$ & 107385 & 37310 & 70075 & 1.88 \\
\hline 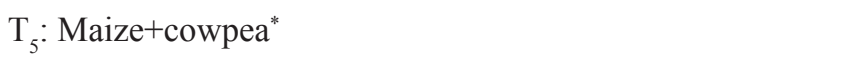 & 143024 & 38745 & 104279 & 2.69 \\
\hline $\mathrm{T}_{6}$ : Atrazine @ 1.0 a.i. ha ${ }^{-1} \mathrm{PE}+1 \mathrm{H}$ & 108972 & 40150 & 68822 & 1.71 \\
\hline $\mathrm{T}_{7}$ : Metribuzin@ $0.25 \mathrm{~kg}$ a.i.ha ${ }^{-1}+1 \mathrm{H}$ & 111480 & 40710 & 70770 & 1.74 \\
\hline $\mathrm{T}_{8}$ : Oxyfluorfen@0.15 kg ha ${ }^{-1}+1 \mathrm{H}$ & 105160 & 41035 & 64125 & 1.56 \\
\hline $\mathrm{T}_{9}$ : Weedy check & 61324 & 35000 & 26324 & 0.75 \\
\hline $\mathrm{T}_{10}:$ weed free & 142532 & 40990 & 101542 & 2.48 \\
\hline $\mathrm{CD}(p=0.05)$ & 12423 & & 12423 & 0.32 \\
\hline
\end{tabular}

"Two rows of cowpea raised in maize as smother crop followed by mulched at 25 DAS; H: Hand hoeing at 25 DAS 


\subsection{Economics}

The economic return is the main aim of any intervention made in traditional package of practices raising crop. The data on economic analysis presented in Table 3 revealed that the maximum gross return of ₹ $1,43,024 \mathrm{ha}^{-1}$ was calculated when the crops were grown in maize+cowpea $\left(\mathrm{T}_{5}\right)$ which obtained at par with weed free $\left(\mathrm{T}_{10}\right)$. Whenever, the net return and $\mathrm{B}: \mathrm{C}$ ratio of cropping system was varied widely with direct and residual effect of different weed control treatments. The maximum net return ( $₹ 1,04,279 \mathrm{ha}^{-1}$ ) and $\mathrm{B}: \mathrm{C}$ ratio (2.69) obtained with maize+cowpea which was significantly superior over rest of treatment in maize-wheat cropping system. The B:C ratio in maize+cowpea treatment was calculated significantly $38.73,30.22$, 37.89 and $72.06 \%$ higher over mean of $\mathrm{PE} \mathrm{PE}+\mathrm{POE}, \mathrm{PE}+1$ hand hoeing and weedy check, respectively. However, minimum net return ( $₹$ $\left.26,324 \mathrm{ha}^{-1}\right)$ and $\mathrm{B}: \mathrm{C}$ ratio $(0.75)$ of the maize-wheat cropping were obtained in weedy check treatment. The highest net return and $\mathrm{B}: \mathrm{C}$ ratio of cropping system in maize + cowpea treatment might be due to increased system productivity due to least weed-crop completion and moisture conservation in maize crop to direct effect of smother effect up to 25 DAS and living mulching of cowpea and enhanced wheat yield to residual effect of cowpea. Similarly, findings were observed by Singh et al. (2015); Sharma and Pankaj (2013) that clearly indicating the inclusion of cowpea not only increases economic profit but also providing environment friendly option against use of chemical herbicides.

\section{Conclusion}

Inclusion of cowpea in maize as living mulch is not only increased the profit but also provide an environment friendly option against use of chemical herbicides by suppressed weeds, reduced weed growth and enhanced resources availability for crop growth and productivity along with changing environmental factors to reduce chemical herbicides application.

\section{References}

Adigbo, S.O., Iyasere, E., Fabunmi, T.O., Olowe, V.I.O., Adejuyigbe, C.O., 2013. Effect of spatial arrangement on the performance of cowpea/maize intercrop in derived Savannah of Nigeria. American Journal of Experimental Agriculture 3(4), 959-70.

Dass, S., Kumar, A., Jat, S.L., Parihar, C.M., Singh, A.K., Chikkappa, G.K., Jat, M.L., 2012. Maize holds potential for diversification and livelihood security. Indian Journal of Agronomy 57 ( $3^{\text {rd }}$ IAC Special Issue), 32-37.

Dubey, R.P., 2008. Effect of weed control and nitrogen rates on weed infestation and productivity in maize-cowpea intercropping system. Indian Journal of Weed Science 40 (3\&4), 155-158.

Gomez, K.A., Gomez, A.A., 2010. Statistical procedures for agriculture research. Wiley Indian Pvt. Ltd., New Delhi, India.

Kandasamy, O.S., Chandrasekhar, C.N., 1998. Comparative efficacy of chemical and non-chemical methods of weed management in rainfed maize (Zea mays L.). Indian Journal of Weed Science 30 (3\&4), 201-203.

Kumar, A., Kumar, J., Puniya, R., Mahajan, A., Sharma, N., Stanzer, L., 2015. Weed management in maize-based cropping system. Indian Journal of Weed Science 47(3), 254-266.

Liebman, M., Davis, A.S., 2000. Integration of soil, crop and weed management in low external-input farming systems. Weed Research 40, 27-47.

Nadiger, S., Babu, R., Arvind Kumar, B.N., 2013. Bioefficiency of pre-emergence herbicides on weed management in maize. Karnataka Journal of Agricultural Science 26(1), 17-19.

Pandey, A.K., Singh, P., Prakash, V., Singh, R.D., Chauhan, V.S., 1999. Direct and residual effect of weed control measures in maize (Zea mays) and wheat (Triticum aestivum) cropping system under mid-hill conditions of north-western Himalayas. Indian Journal of Weed Science 31 (3\&4), 204-209.

Peterson, T.A., Russelle, M.P., 1991. Alfalfa and the nitrogen cycle in the Corn Belt. Journal of Soil Water Conservation 46, 229-235.

Sharma, R., Pankaj., 2013. Direct and residual effect of different herbicides applied in maize (Zea mays) on weed dynamics and productivity of maize and succeeding wheat (Triticum aestivum). Indian Journal of Agricultural Sciences 83(1), 77-82.

Sharma,V., Thakur, D.R., 1998. Integrated weed management in maize (Zea mays) under mid-hill condition of north-western Himalayas. Indian Journal of Weed Science 30 (3\&4), 158-162.

Singh, A.K., Parihar, C.M., Jat, S.L., Singh, B., Sharma, S., 2015. Weed management strategies in maize (Zea mays): Effect on weed dynamics, productivity and economics of the maizewheat (Triticum aestivum) cropping system in Indo-gangetic plains. Indian Journal of Agricultural Sciences 85(1), 87-92.

Talebbeigi, R.M., Ghadiri, H., 2012. Effect of cowpea living mulch on weed control and maize yield. Journal of biology and environmental science 6(17), 186-193.

Teasdale, J.R., 1996. Contribution of cover crops to weed management in sustainable agricultural systems. Journal of production agriculture 9(4), 475-479.

Teasdale, J.R., Mohler, C.L., 1993. Light transmittance, soil Temperature, and soil moisture under residue of hairy vetch and rye. Agronomy Journal 85, 673-80. 